Executives in Tokyo last November. "But it

$₹$ has yet to happen in Japan."

According to the economic-growth strategy, only two regenerative medicine products had been approved in Japan by December 2012, compared with nine in the United States and 14 in South Korea. Ryuichi Morishita, a gene-therapy specialist at Osaka University and one of the government's advisers on the proposals for the Japanese version of the $\mathrm{NIH}$, agrees that the country needs more research translation. "Thanks to powerful political leadership, Japan is finally about to break the walls, a feat that has been attempted many times in the past but always ended in vain," he says.

But the government's plans came under fire from researchers before they had even been published. Days before the two strategies were approved by the cabinet, seven major life-science societies issued an emergency statement, calling for basic research to be supported. The next day, a further 54 bioscience associations warned that cuts to Grant-in-Aid for Scientific Research, Japan's main competitive funding stream for curiosity-driven research, would damage the country's ability to nurture the next generation of researchers.

Officials have since sought to allay these fears. "We are aiming to produce novel drugs, medical technologies and therapies," says Shin Okuno, director of the Office of Healthcare Policy, the government body charged with implementing the healthcare strategy. "But it doesn't mean we don't understand the importance of basic science."

The strategies say that implementation of the proposal could start by the end of August, when the government will establish an internal administrative office to flesh out details such as the organization and budget of the body. Parliament is expected to pass a bill to establish the institute next year, allowing a launch as soon as 2015.

To avoid starting from scratch, one of Japan's existing medical-research institutes is likely to be turned into the main coordinating agency, with other institutes under its control. The Japanese NIH's top priority will be cancer research, but the institute will also focus on areas such as regenerative medicine, dementia, next-generation vaccines and diseases such as atherosclerosis.

The speed with which plans are moving has worried many senior researchers. Tetsuo Noda, president of the Japanese Cancer Association in Tokyo, largely agrees with the idea of centralizing the budget for research on human health and diseases, but warns that scientists have not been widely consulted. "It was a bit of a hasty move," he says. "There's a top-down approach, with government officials working on a vague concept. That won't lead to an excellent medical-research system." -

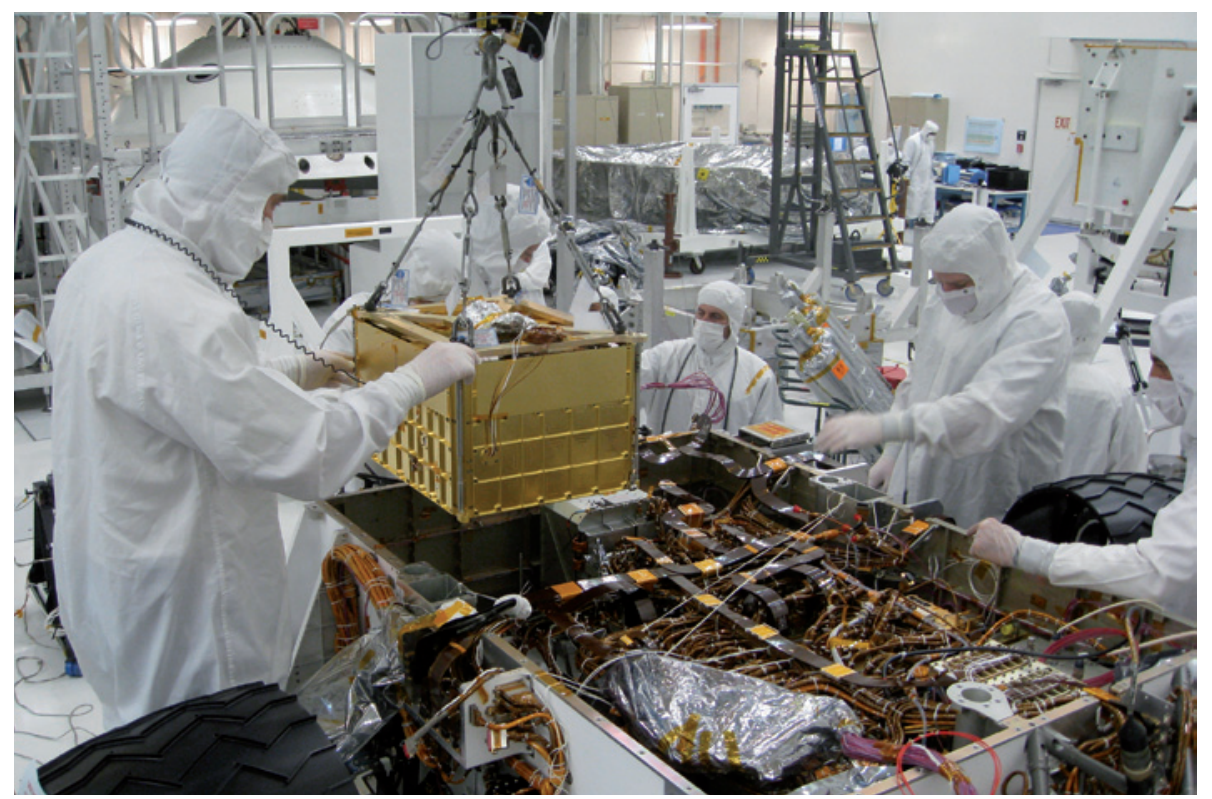

Equipment made by Creare, an SBIR grant recipient, is loaded into the Mars Science Laboratory rover.

FUNDING

\title{
US research firms put under pressure to sell
}

\section{Commercialization rules threaten to curtail SBIR grants.}

\section{BY EUGENIE SAMUEL REICH}

$\mathrm{T}$ The offices of Physical Sciences Inc. (PSI), a small scientific research company in Andover, Massachusetts, feel not too dissimilar from a technical university. The brick and glass building boasts an atomic oxygen chamber for testing how new materials act in outer space, as well as a next-generation ophthalmic device that makes high-resolution maps of the retina. Chief executive Dave Green looks like an academic as he hangs out in the atrium wearing a baseball cap; the only sign that he operates a for-profit business is the shirt and tie that hide beneath his zip-up sweater.

PSI, in fact, is not much of a commercial operation. Most of its revenue comes from research performed for larger companies and the government, and nearly one-third of it, US $\$ 10.5$ million, comes directly from a single federal source: the US Small Business Innovation Research (SBIR) programme. According to guidance from the Small Business Administration, which oversees the programme, the grants are supposed to lead to commercial activity and are not merely to fund long-term research operations. However, an analysis by Nature of government data suggests that the top award winners are research-focused companies such as PSI that do not sell products, and many companies depend on SBIR funding, year after year, for a large part of their revenue stream (see 'Small business, big awards').

That era may be about to end.

The SBIR programme is based on the requirement that government agencies set aside $2.7 \%$ of their research budgets, about $\$ 2$ billion per year in total, for grants to small businesses. In 2011, Congress reauthorized it for another five years but added requirements that the Small Business Administration track the outcomes of the grants. To facilitate this, the administration issued policy guidelines last year requiring agencies to monitor commercialization more closely. A set of benchmarks for doing so were due out on 1 July, although they have been delayed owing to employee turnover, according to a Small Business Administration spokesman.

If the benchmarks have any teeth to them, companies such as PSI, which has never brought a product to market in its 30-year history of winning SBIR awards, will struggle. "The explicit commercial side of it, if it's really enforced, is going to cause problems for companies like us, says Greg Zacharias of Charles River Analytics, a research and development company in Cambridge, Massachusetts, that won 44 SBIR awards worth a total of $\$ 8.8$ million in 2011 .

It is not as if these research and 
- development firms are unproductive. With a history of SBIR awards going back two decades, PSI has flown an instrument on the space shuttle to study gas release and ionization, put a fuel-quality monitor into a US Navy aircraft carrier and developed a helicopter-like device for the US Department of Defense that is the size of a human hand and can fly a reconnaissance camera at up to 89 kilometres per hour.

The problem with asking agencies to measure commercialization, says Green, is that it can take many forms besides selling on the open market. To him, commercialization also includes selling prototypes to the government agencies that initially funded their development, filing and licensing patents, and spinning off technologies - something PSI did with an earlier generation of the ophthalmic device, which is now being sold to hospitals. Although the effect of the new reporting requirements and benchmarks has yet to be seen, some SBIR-supported scientists fear that the changes will strongly favour companies that bring products to market, an approach that is at odds with PSI's business model. "Our goal is not necessarily that we build a product," says Green, "but that someone builds it."

Justifying the research focus of certain SBIR companies has always been tough. Some critics call the companies 'mills', a pejorative reference to the number of grant applications they crank out each year. About $1 \%$ of companies receiving SBIR support get $13 \%$ of the funds, according to Nature's analysis. The top award holder in 2011 was Physical Optics Corporation in Torrance, California, which specializes in integrating components into working systems, such as data recorders for the Navy's T-45 aircraft. In 2011 it won 94 awards worth $\$ 32$ million, which made up 63\% of its annual revenue of $\$ 51$ million. Company spokesman Rick Shie says that these numbers are not the whole story: Physical Optics has a strong commercial side that since 1985 has shipped products worth more than $\$ 200$ million.

\section{"Our goal is not necessarily that we build a product, but that someone builds it."}

However, there is little doubt that it and others retain a strong research focus. "The mills exist," says Zoltan Acs, an expert on entrepreneurship at George Mason University in Fairfax, Virginia, who used to work at the Small Business Administration. "If you want to defend the system, you have to defend the mills."

The companies argue that they are using government dollars to fulfil crucial US research needs, even if they are not pioneering consumer products. For example, the company that won the second-largest slice of grant money in 2011 - Creare in Hanover, New Hampshire - has provided important equipment to NASA. It developed vacuum pumps for a sample-analysis instrument on the Curiosity Mars rover and built cooling systems

\section{SMALL BUSINESS, BIG AWARDS}

Just $1 \%$ of the companies receiving grants from the US Small Business Innovation Research (SBIR) programme get $13 \%$ of the money. Some companies depend on the awards for most of their revenue, indicating that they do not generate much money from commercial products. Here are the top ten award winners in 2011.

\begin{tabular}{l|c|c|c|c}
\hline Company & $\begin{array}{c}\text { Number of SBIR } \\
\text { awards in 2011 }\end{array}$ & $\begin{array}{c}\text { Total award } \\
\text { amount (US } \$ \text { ) }\end{array}$ & $\begin{array}{c}\text { Approximate number } \\
\text { of employees }\end{array}$ & $\begin{array}{c}\text { Approximate } \\
\text { annual revenue }\end{array}$ \\
\hline $\begin{array}{l}\text { Physical Optics } \\
\text { Corporation }\end{array}$ & 94 & $\$ 32,048,692$ & 235 & $\$ 50,800,000$ \\
\hline $\begin{array}{l}\text { Creare } \\
\begin{array}{l}\text { Intelligent } \\
\text { Automation }\end{array}\end{array}$ & 51 & $\$ 14,746,902$ & 118 & $\$ 23,000,000$ \\
\hline $\begin{array}{l}\text { Radiation Monitoring } \\
\text { Devices }\end{array}$ & 32 & $\$ 14,567,686$ & 130 & $\$ 27,000,000$ \\
\hline $\begin{array}{l}\text { Infoscitex } \\
\text { Corporation }\end{array}$ & 28 & $\$ 12,987,429$ & 140 & $\$ 31,000,000$ \\
\hline $\begin{array}{l}\text { Combustion } \\
\text { Research and Flow } \\
\text { Technology }\end{array}$ & 22 & $\$ 10,936,637$ & 39 & Not available \\
\hline $\begin{array}{l}\text { Lynntech } \\
\text { Physical Sciences }\end{array}$ & 38 & $\$ 10,789,277$ & 135 & Not available \\
\hline $\begin{array}{l}\text { Inc. } \\
\text { CFD Research } \\
\text { Corporation }\end{array}$ & 32 & $\$ 10,533,749$ & 180 & $\$ 35,000,000$ \\
\hline \begin{tabular}{l} 
Agiltron Corporation \\
\hline
\end{tabular} & 33 & $\$ 9,382,591$ & 90 & $\$ 17,000,000$ \\
\hline
\end{tabular}

SBIR awards can exceed revenues because awards can be out of sync with companies' fiscal years and because monies can be routed to subcontractors. Award totals also include monies from the Small Business Technology Transfer programme.

for the Hubble Space Telescope. However, the market for such technology will always be small because of the limited number of space missions and the unique nature of components such as the Hubble cooling system. "It was a one-off, but it was fantastic," says Charles Wessner, a policy expert at the US National Academy of Sciences in Washington DC who commends the SBIR programme.

Charles River Analytics has a few nongovernment clients, although it specializes in developing command and control software for the military. Zacharias says the last time his company sold a commercial product was in the 1990s, when a website personalization tool it developed was sold to another company that in turn sold it to the software developer Adobe. "If someone asked us what was the commercial output of that, it would take a bunch of forensic accountants," he says.

How exactly commercialization should be measured will become clearer when government agencies define their commercialization benchmarks, but Matthew Portnoy, programme coordinator for the SBIR at the National Institutes of Health, says the principle behind them will be clear. "We're always interested in a product ultimately getting to market," he says. Although programme managers have been working to measure commercial success in a nuanced way, they do have to honour Congress's apparent desire to shift the programme's direction away from research, he adds.

When the SBIR programme was conceived in 1982, fulfilling governmental research needs was seen as an end in itself, and a goal that could exist alongside the commercialization of products. And agencies have always preferred to steer money to their own priorities, says Ann Eskesen, a technology-transfer expert in Swampscott, Massachusetts. The real value of SBIR companies, she says, is as a reservoir of distributed research and development that can serve US business. With the decline of research and development laboratories at corporations, larger firms that have sudden scientific need often buy up several SBIR companies to solve their research problems. Her tally of SBIR acquisitions shows that General Electric has bought 12 SBIR-supported companies, defence giant Lockheed Martin has bought 10 and biotechnology company Genzyme has bought 6 .

PSI is unlikely to be bought, says Green, although he says that the company will continue to try to spin off technologies. Still, he likes the analogy to a corporate research and development department. The difference is that in many companies, product commercialization makes the researchers who did the work redundant. At PSI, when work is spun off or licensed, researchers stay on the payroll and turn to a new research problem — and a new SBIR award. "We're a research company and proud of it," he says. "Researchers don't get along in product companies."

\section{CORRECTION}

The News Feature 'The quantum company' (Nature 498, 286-288; 2013) should have noted that researchers at the University of Southern California worked with Lockheed Martin on D-Wave's debugging algorithm. 